\title{
原著変形性膝関節症に対する湧泉、三陰交部の ホットスパイク刺激の効果
}

\author{
三原 憲一* 王 財 源 田良原 稔文
}

要旨 関節内浸出液を呈す変形性膝関節症患者に対して, 湧泉及び三 㓌交穴を用いて，局所温熱療法と対比してみた。温熱療法の代表であ る電気ホットパックを用いて，局所に加温を行い，一方，遠隔部誘導 をホットスパイクで, 涌泉と三陰交に求めて治療を進めた。

遠隔部誘導は局所温熱療法と比較して, 関節内浸出液の増減に対し て安定している。

但し，今回は膝蓋骨周囲径を測定して，その基準とし，同一施術者 で測定時の基準設定を行い誤差が極力生じないように注意を払った。 観察期間中は他の治療法や運動等は一切中止させた。

\section{I はじめに}

変形性膝関節症は，滕蓋骨及びその周囲の慢性 退行性変化(軟骨) と, 増殖性変化(骨)により発症 し，主症状は炎症による関節の疼痛，運動制限， 膝関節内浸出液貯溜である。

本症は予後が比較的良好でない上に，近年増加 傾向にあり，専門家領域においても治療技術の向 上が望まれる疾患である。筆者らは湧泉穴と三㓌 交穴に, 電気低周波刺激が, 変形性膝関節症に対 して，若干の効果が期待できる結果が得られた。 特に家庭における低周波治療器の普及により， その個々の家庭内でも簡単に行なうことが可能な 治療方法として，足底通電 (湧泉, 三㓌交)を用い て, 関節内浸出液に対しての変化を観察した。

* Kenichi MiHARA からと整形外科リハビリテーション研 究所

共同研究者：WANG Cai YUAN からと整形外科リハビリテ ーション研究所

Toshifumi TARAHARA からと整形外科院長

Key Words : 変形性膝関節症, 電気低周波

\section{II 研 究方法}

対象は，からと整形外科に通院中の外来患者で, 男性 2 名，女性 10 名，計 12 名で，いづれの場合も 関節内浸出液貯溜経歴をもち，50歳から70歳まで の ROM制限が認められない変形性膝関節患者とし た。

通電方法は日本メデックス社製SSP システム 5004 型ホットスパイク湿性導子を使用し，刺激部位は 患側の湧泉と三陰交穴に $3: 30 \mathrm{~Hz}$ の Mix 波で15分 間刺激とした。出力は患者の耐え得ることが出来 る範囲で行なった。

又，施術後の膝蓋骨周囲径を中心に大腿周囲径， 膝蓋骨下方 5 センチの測定を行なった通電は 4 週 間とし，その期間中における膝関節周囲を観察し た。観察期間中は他の治療方法は一切行なわなか った。温熱療法の代表であるホットパック(局部刺 激)との比較で, 局部刺激と遠隔部(足底)刺激の効 果を調査した。

\section{III 研 究 結 果}

足底(湧泉, 三㓌交)に4週間通電をした結果(Fig.1)， 足底通電群が温熱療法群と比較して, 膝蓋骨周囲 
$t=3.3475>t .(0.02)$

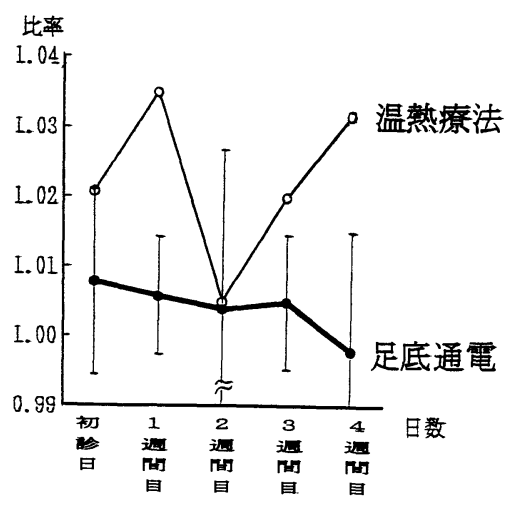

Fig. 1 足底群と温熱群との比較

径の比率が安定していた。それに対して温熱療法 群の比率は不安定であった。

これら 2 種の療法に対して，等分散の検定及び 等平均の検定を行なったところ, t分布表により自 由度 8 , 有意水準 $2 \%$ で $\mathrm{t}_{8}(0.02)=2.896$ で, $|\mathrm{t}|=$ 3.3475 であり $|\mathrm{t}|>\mathrm{t}_{8}$ (0.02)が成立し，その有意 差が認められた。

\section{IV 考察}

膝関節疾患は長期負荷重または退行性変化によ り，軟骨あるいは骨に影響を及ぼす疾患で，時に 関節内浸出液等が認められる。

リハビリテーション医学において, 大腿四頭筋 の通電により筋力強化に作用することが旭川医大 整形外科の小野沢らの報告にもあり長期間の通電 刺激によって筋力強化を促進し膝関節強化に連動 する有効性が述べられている。又, 従来のリハビ リテーションでは，負荷による自動抵抗運動が大 腿四頭筋強化に結びつけれるため, 治療の一手段 として用いられてきた。

中国の古典「素問：骨空論」より経穴の特性を活 かし, 経穴通電が膝関節疾患に対する影響を観察 した。現在, 中国における研究では, 成都中医学 院の宋開源らの報告によると湧泉穴に刺針を行な った場合は, NE（ノルエピネフリン）と5-HT（ヒ ドロキシトリプタミンくセロトニン〉)の分泌に対し, 有効であり, これらは気分, 快楽, 及び脳の興奮 性を制御する重要な役割を果たすと言われるが,
アドレナリンアルファレセプタに対して，ノルエ ピネフリンはエピネフリンよりも感受性が高く, これらは血管平滑筋と腸管及び膀胱の活約筋の収 縮と, 脾臓の収縮をひき起こす。これらは, しば しば細胞内 $\mathrm{Ca}^{2+}$ 濃度を増加させることによって, 筋収縮や分泌をひき起こすように働く。又, 体温 調節にも関連することから，湧泉穴を選穴した。 三除交刺針では, T細胞の量が増加するとの報告 があり, 刺針前 $42.56 \pm 2.22 \%$ が刺針30分後に55.30 $\pm 2.15 \%$ に増加, 逆に抜針後30分目に $51.18 \pm 2.52 \%$ が60分目に $47.43 \pm 2.07 \%$ に減少し，非経穴群で 同様なテストを行なったが変化を認めず，三陰交 穴の有効性を取り上げていたことから，他の経穴 には無い特性を選んで，この二つの経穴を通電刺 激対象とし変形性膝関節症に対しての変化を観察 した。

通電刺激による筋力増強, 体温調節による循環 改善, 細胞内カルシウムによる血管や筋収縮, リ ンパ細胞の増加による抵抗力や免疫増進, これら の働きによって，退行性及び荷重による基本的要 因が避けられるのではないであろうか。術中に脾 経に沿って経絡線上に通電感覚が上昇する伝導現 象も観られ, 経穴の特性と現代生理学上において, 涌泉, 三陰交穴が局部の温熱刺激と比較して効果 が高いように思われる。

\section{$\mathrm{V}$ おわりに}

1. 局所温熱療法と比較した場合，足底通電に有 意差 $|\mathrm{t}|>\mathrm{t}_{8}(0.02)$ を認めた。

2. 遠隔部(湧泉，三㓌交)刺激で浸出液の抑制が 温熱療法と比較して抑制される傾向を認めた。

3. 大腿四頭筋の強化運動と比較して, 経穴刺激 が人体中のホルモン分泌との関連があるものと 思われる。

稿を終わるに臨み御指導を頂いたからと整形外科院 長田良原稔文博士に謹んで感謝の意を表します。

\section{参考文献}

1）兵頭正義ほか：簡明銊灭医学辞典, 医歯薬出版, 大阪 (1981). 
2) 北出利勝, 兵頭正義ほか: 明瞭な経絡現象を呈 する一症例について(第 2 報), 全日本鍼炎学会 雑誌 33(1);42 49. (1983)

3）王財源：子午流注の納子法が示す日時経脈流注 の循環図について，東洋医学とペインクリニッ ク $13(2)$. (1983)

4）宗開源：涌泉穴刺針による5-HT に対する影響, 世界鍼炎学会連合誌. (1987)

( T650 神戸市中央区楠町5-4-21 からと整形外科附属リハビリ研究所）

\title{
Clinical Effects of the Hot Spike Stimulation at the YUSEN(K-1) and SANINKO(SP-6) for Knee Joint Osteoarthritis(OA)
}

\author{
Kenichi Mihara, Wang Cai Yuan and Toshifumi Tarahara \\ Karato Seikeigeka
}

We compared the results of heating the joint and of applying the Hot-spike and electric stimulus to the YUSEN and SANINKO points to disperse the fluid at the Knee.

The tests with the points resulted in little change in the fluid level at the Knee.

This time we measured the circumference of the Knee. A therapist established the standard measuring method, and tried to make the error decrease.

While they were observing the circumference of the Knee, they would not allow anyother medical treatments or any movement by the patient. 